\title{
Rapid Screening of Mupirocin Skin Permeation Modification by Micronized and Nanonized Alaptide
}

\author{
Radka Opatrilova and Josef Jampilek* \\ Department of Chemical Drugs, Faculty of Pharmacy, University of Veterinary and Pharmaceutical Sciences, \\ Palackeho 1/3, 61242 Brno, Czech Republic \\ *Corresponding Author: E-mail: josef.jampilek@gmail.com; Tel.: +420-541-562-926
}

Received: December 18,2013; Revised: January 28, 2014; Published: April 01, 2014

\begin{abstract}
The investigation deals with the affection of permeation of mupirocin from the Bactroban ${ }^{\circledR}$ Leciva ointment through full-thickness pig ear skin by alaptide that was applied in micronized or nanonized form as a potential excipient. Alaptide, (S)-8-methyl-6,9-diazaspiro[4.5]decan-7,10-dione, was the original Czech compound. It was discovered that micronized alaptide significantly enhanced the permeation of mupirocin within $1 \mathrm{~h}$ after administration (approx. 5-fold). On the other hand, nanonized alaptide almost completely inhibited permeation of mupirocin from Bactroban ${ }^{\circledR}$ Leciva through the skin. Rapid primary screening showed that the two forms of alaptide differently influenced the depth and the rate of permeation/penetration of mupirocin into/through the skin, i.e., affect curative effect of mupirocin on/in skin immediately after application of drug formulation.
\end{abstract}

Keywords: alaptide; mupirocin; nanoparticles; Bactroban ${ }^{\circledR}$

\section{Introduction}

Development in the field of pharmaceutical dosage forms results in the discovery of additional highly sophisticated drug delivery systems that allow for the maintaining of constant levels of active substances in organisms. Transdermal administration of drugs represents an alternative to conventional pharmaceutical dosage forms. However, transdermal drug delivery often faces the problem of insufficient or no penetration of active pharmaceutical substances through the skin, because skin itself is a physiological barrier that protects the body from toxins and microorganisms from the external environment. To solve this critical issue, various approaches to overcoming the skin barrier have been developed. These approaches can be classified as chemical (modification of drugs using transdermal chemical penetration enhancers) or physical (modification of drug particle size to nanosize) enhancement techniques [1-5 and refs. therein].

In general, transport mechanisms support nanomaterial penetration [6-9]; however, the promise of nanoparticle-mediated drug delivery into the epidermis and dermis without barrier modification has met with little success. The penetration of particulate materials into the skin is a very complex issue. Therefore, the interaction of nanoparticles with the skin and especially skin models is an intriguing field of research. However, the data obtained do not show a clear image of the effect of nano-carriers. In particular, the 
penetration of such particles is an open and controversially discussed issue. The literature reports different results primarily on pig or murine skin, showing either strong penetration (pig and mouse) or the opposite. Looking only at the sizes of the particles, no conclusive picture can be obtained. The fact that nanoparticles did not penetrate/permeate or expressed decreased penetration/permeation was described and discussed in a number of recent papers [10-15].

Our team focused on investigating a slightly different topic, namely the influence of a transdermal chemical penetration enhancer (CPE) in micronized and/or nanonized form on the modification of the permeation/penetration properties of a drug through the skin. In this investigation alaptide was chosen as a potential CPE and mupirocin was selected as a tested drug. Alaptide (chemically, (S)-8-methyl-6,9diazaspiro[4.5]decan-7,10-dione, see Fig. 1) is an original Czech compound that was prepared by Kasafirek et al. in the 1980s $[16,17]$. During biological assays, it was found that alaptide affected the behaviour and learning abilities of rodents, particularly rats and mice; as such, it can be classified as nootropic [18-20].

Alaptide also expressed anti-proliferative activity [21] and immunomodulatory effect [22]. Additionally, alaptide reduced the number and the extent of experimental gastric ulcers. The gastric juice quantity, acidity and enzymatic activity were not influenced $[23,24]$. Alaptide was tested on the diploid cell line of a human embryonic lung LEP-19, where it expressed a stimulating effect on the growth and breeding of cells without transformation changes in their morphology. In vitro tests also showed that alaptide increased cell proliferation; both the above mentioned effects can significantly contribute to the curative effect of alaptide.

An influence of alaptide on epidermal regeneration was investigated in a number of tests. In vivo experiments were performed using domestic pigs to which alaptide was applied on experimental injury; faster skin regeneration was observed after alaptide application. Similarly, alaptide accelerated curing of experimental skin injuries in rats $[17,25]$. As alaptide was designed as an analogue of melanocytestimulating hormone release-inhibiting factor (MIF-1), it negatively affects the inhibition of the release of melanocyte-stimulating hormone and thus increases the concentration of melanocytes in the epidermis.

Melanocytes significantly influence the creation and function of keratinocytes by means of melanosomes [26-28]. Metabolic studies in rats showed that alaptide is readily absorbed from the gastrointestinal tract and penetrates the blood-brain barrier [17,21]. It is excreted unchanged, mostly via urine (90\%); a similar metabolic profile was also found in humans [29]. Any toxicity (acute, subchronic and chronic) as well as genotoxic, teratogenic and embryotoxic effects of alaptide were not observed $[17,21,30]$. Additionally, it was found that both alaptide enantiomers did not induce the biotransformation enzymes $(1 A 1,1 A 2,1 B 1)$ of the cytochrome P450. These enzymes are critical in the bioactivation of procarcinogens and are upregulated, inter alia, by ultraviolet-B radiation in the skin [31,32].

Based on the above mentioned facts and structural analogy with other CPEs, it was suggested to evaluate alaptide as a potential CPE of many anti-inflammatory drugs, antimicrobial chemotherapeutics, sex hormones/genital system modulators, or drugs targeting the central/vegetative nervous system $[4,32,33]$. Furthermore, the permeation of micronized (ALA) and nanonized (NALA) alaptide alone through the full-thickness pig ear skin from various semi-solid compositions was evaluated and different behaviour among both forms was confirmed. Though permeation of NALA through the skin was limited compared with ALA [34], NALA was also positively evaluated as a potential modifier of transdermal permeation $[32,33]$. Thus, the aim of this primary rapid study was to evaluate the effect of alaptide in micronized and nanonized forms on drug permeation through the skin immediately after application of the drug formulation. 
Mupirocin (pseudomonic acid A, chemically 9-\{[(2E)-4-[(2S,3R,4R,5S)-3,4-dihydroxy-5-\{[(2S,3S)-3[(2S,3S)-3-hydroxybutan-2-yl]oxiran-2-yl]methyl\}oxan-2-yl]-3-methylbut-2-enoyl]oxy\}nonanoic acid, see Fig. 1) is an antibiotic originally isolated from Pseudomonas fluorescens and is structurally unrelated to any other antibiotics. It is used topically and primarily effective against Gram-positive bacteria, such as Staphylococcus aureus (including methicillin-resistant S. aureus) and beta-hemolytic streptococci, including $S$. pyogenes. It can be used for treatment of furuncles, impetigo, open wounds, etc. Mupirocin is bacteriostatic at low concentrations and bactericidal at high concentrations. It has a unique mechanism of action, which is selective binding to bacterial isoleucyl-tRNA synthetase, which halts the incorporation of isoleucine into bacterial proteins. Following intravenous or oral administration, mupirocin is rapidly metabolised. The principal metabolite is monic acid, which has no antibacterial activity; therefore, its indication is topical treatment of bacterial skin infections. Mupirocin is mostly formulated as $2 \%$ macrogol ointment and was originally marketed by GlaxoSmithKline under trade name Bactroban ${ }^{\circledR}$ [35-37]. In a rapid in vitro screening, the effect of both forms of alaptide on permeation of mupirocin from Bactroban ${ }^{\circledR}$ Leciva ointment through full-thickness pig ear skin using a Franz cell was investigated.<smiles>CC1NC(=O)C2(CCCC2)NC1=O</smiles>

alaptide<smiles>C/C(=C\C(=O)OCCCCCCCCC(=O)O)C[C@@H]1OC[C@H](C[C@@H]2OC2C(C)C(C)O)[C@H](O)[C@H]1O</smiles>

Figure 1. Structures of (S)-alaptide and mupirocin.

\section{Experimental}

\section{Preparation of alaptide}

Alaptide was synthesised according to the standard process [38]. All reagents were purchased from Aldrich and Merck. Alaptide was micronized using a Planetary Ball Mill PM 200, Retsch (Germany). The particle size of the used micronized alaptide was measured by a NIKON Optiphot 2 microscope with a VDS CCD-1300F digital camera. The particle size distribution $\left(x_{90}\right)$ of microcrystalline alaptide was $40 \mu \mathrm{m}$.

The suspension of alaptide $(30 \mathrm{~g})$, polyvinylpyrrolidone $(30 \mathrm{~g})$ and purified water $(240 \mathrm{~mL}$, diluted during milling by the addition of $150 \mathrm{~mL}$ ) was initially mixed for $12 \mathrm{~h}$ at ambient temperature and then filtered through a mill sieve. The milling procedure was performed using a nanomill NETZSCH (Germany) with glass beads $(0.3 \mathrm{~mm})$; the rotor speed was $986 \mathrm{rpm}$; the pump speed was $30 \mathrm{rpm}$; the temperature in the grinding chamber was within $17-20^{\circ} \mathrm{C}$. The rotor speed was increased to $1500 \mathrm{rpm}$ after $6 \mathrm{~h}$ of milling. The total time of milling was $57.5 \mathrm{~h}$. The content of alaptide in the suspension was $38.76 \mathrm{~g} / \mathrm{L}$ (determined by RPHPLC, see below). The particle size of the prepared nanonized alaptide was measured by Sympatec NANOPHOX $0138 \mathrm{P}$ (Germany) and the particle size $\mathrm{x}_{90}$ was $770 \mathrm{~nm}$.

\section{In vitro transdermal permeation experiments}

Skin samples were obtained from a porcine ear. Full thickness ear skin was cut in fragments and stored at $-20^{\circ} \mathrm{C}$ until utilised. Skin samples were slowly thawed (at $4{ }^{\circ} \mathrm{C}$ overnight and then at ambient temperature) prior to each experiment. The penetration enhancing effect of micronized alaptide (ALA) and nanonized alaptide (NALA) was evaluated in vitro, using a vertical Franz diffusion cell (SES - Analytical Systems, Germany) with a donor surface area of $0.6359 \mathrm{~cm}^{2}$ and a receptor volume of $5.2 \mathrm{~mL}$. The skin was mounted between the donor and receptor compartments of the Franz diffusion cell with the epidermal side up. The receptor compartment was filled with phosphate buffered saline $(\mathrm{pH} 7.4)$ and maintained at 
$34 \pm 0.5^{\circ} \mathrm{C}$ using a circulating water bath. The receptor compartment content was continuously stirred using a magnetic stirring bar. The skin was kept in contact with the receptor phase for $0.5 \mathrm{~h}$ prior to the experiment. BACTROBAN ${ }^{\circledR}$ Leciva ( $2 \%$ macrogol ointment produced by Zentiva Prague, Czech Republic) was purchased from a pharmacy. The ointment was mixed with ALA or NALA ( $1 \%$ related to drug); ALA or NALA dissolved in the ointment and the prepared monophasic compositions were applied to the skin surface as a donor sample and the donor compartment of the cell was covered by Parafilm ${ }^{\circ}$. BACTROBAN ${ }^{\circledR}$ Leciva was $^{\circ}$ used as a control. Samples $(0.5 \mathrm{~mL})$ of the receptor phase were withdrawn at four pre-determined time intervals (30,60, 90 and $120 \mathrm{~min}$ ) and the cell was refilled with an equivalent amount of fresh buffer solution. A minimum of five determinations was performed using skin fragments from a minimum of two animals for each compound and the data was expressed as means \pm SD. The samples were immediately analysed by HPLC.

Analysis of samples was performed using an Agilent 1200 series HPLC system equipped with a diode array detection (DAD) system, a quaternary model pump and an automatic injector (Agilent Technologies, Germany). Data acquisition was performed using ChemStation chromatography software. A Zorbax Eclipse XDB C18 $5 \mu \mathrm{m}, 4.6 \times 150 \mathrm{~mm}$ (Agilent, USA) chromatographic column was used. The total flow of the column was $0.5 \mathrm{~mL} / \mathrm{min}$; injection was $10 \mu \mathrm{L}$; column temperature was $30^{\circ} \mathrm{C}$; sample temperature was $10^{\circ} \mathrm{C}$. The detection wavelength of $210 \mathrm{~nm}$ was chosen and the time of analysis was eight minutes. A mixture of $\mathrm{MeOH}$ (HPLC grade, 75.0\%) and $\mathrm{H}_{2} \mathrm{O}$ (HPLC - Mili-Q Grade, 25.0\%) was used as a mobile phase. Mupirocin standard was purchased from Sigma-Aldrich. The retention time $\left(t_{R}\right)$ of mupirocin was $3.4 \pm 0.05$ min; the limit of detection (LOD) was $9.5 \mathrm{ng} / \mathrm{mL}$; the limit of quantification (LOQ) was $31.7 \mathrm{ng} / \mathrm{mL}$.

\section{Results and Discussion}

Mupirocin was chosen as a frequently applied antibiotic for topical treatment of bacterial skin infections that are often associated with various injuries of the skin, because alaptide itself showed significant curative effect on the skin $[17,25]$. It was supposed that alaptide could influence the time of mupirocin retaining on/in the skin and act synergistically with this antibiotic. The rapid in vitro skin permeation screening experiments were performed using static Franz diffusion cells [39] in a time limit of two hours only. Full-thickness pig ear skin was selected for in vitro evaluation of permeation. This tissue is a suitable in vitro model of human skin $[40,41]$, because porcine skin has shown to be histologically and biochemically similar to human skin and has previously been used in numerous studies [42]. The permeation of mupirocin through full-thickness pig ear skin with and without $1 \%$ ( $w / w$ related to drug) ALA or NALA was tested using BACTROBAN $^{\circledR}$ Leciva, i.e., macrogol ointment as a donor vehicle. The results are listed in Table 1 and illustrated in Figure 2.

Table 1. Cumulative permeated amounts $Q_{t}$ per unit area $\left[\mu \mathrm{g} / \mathrm{cm}^{2}\right]$ of mupirocin (MUP) from BACTROBAN ${ }^{\circledR}$ Leciva (macrogol ointment) with and without micronized (ALA) or nanonized (NALA) alaptide as a modifier of transdermal permeation achieved in in vitro transdermal permeation experiments using the Franz diffusion cell. $Q_{t}$ are expressed as mean $\pm S D$ ( $n=5$ experiments).

\begin{tabular}{cccc}
\hline \multirow{2}{*}{ Time $[\mathrm{h}]$} & \multicolumn{3}{c}{ Cumulative permeated amounts $Q_{t}$ per unit area[ $\left[\mathrm{mg} / \mathrm{cm}^{2}\right]$} \\
\cline { 2 - 4 } & MUP & MUP+ALA & MUP+NALA \\
\hline 0.5 & $301.1 \pm 5.8$ & $730.4 \pm 6.9$ & $105.8 \pm 4.7$ \\
1.0 & $403.7 \pm 6.0$ & $1951.8 \pm 8.6$ & $158.3 \pm 4.9$ \\
1.5 & $2861.7 \pm 15.0$ & $2337.1 \pm 7.0$ & $208.4 \pm 7.4$ \\
2.0 & $4062.7 \pm 14.2$ & $3055.2 \pm 3.5$ & $248.7 \pm 8.8$ \\
\hline
\end{tabular}




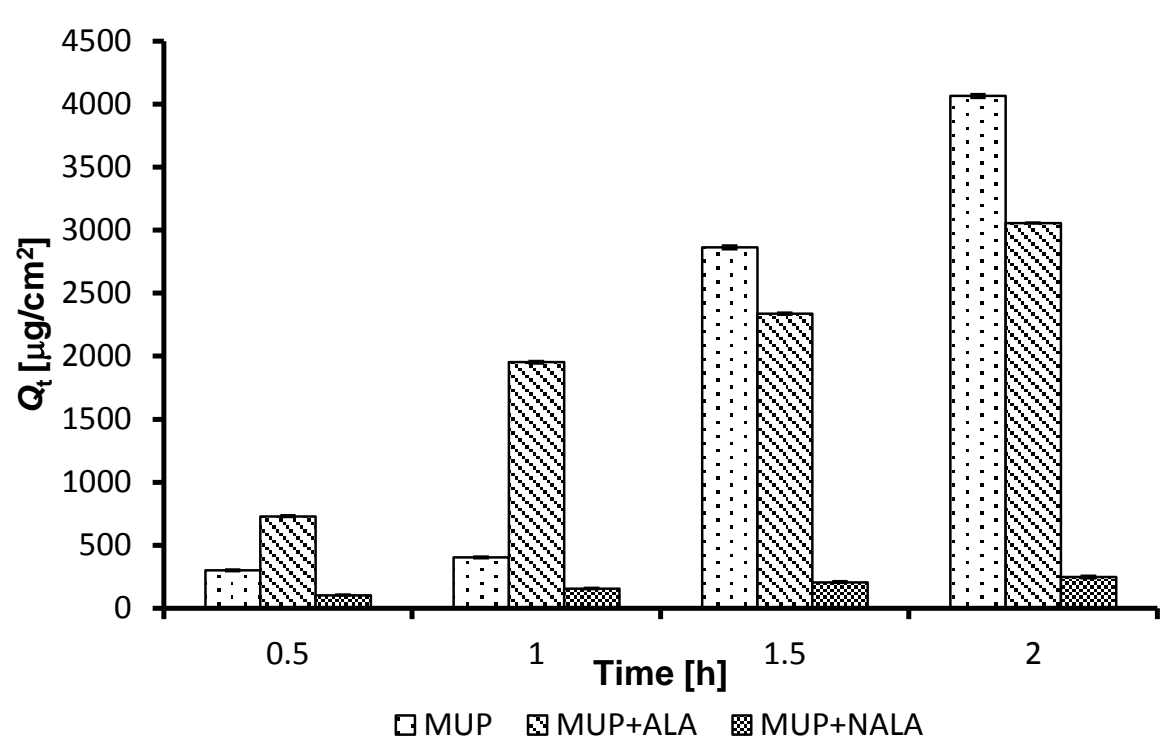

Figure 2. In vitro profile of cumulative permeated amounts $Q_{t}$ per unit area $\left[\mu \mathrm{g} / \mathrm{cm}^{2}\right]$ in time of mupirocin (MUP) alone and after addition of $1 \% \mathrm{w} / \mathrm{w}$ of micronized (ALA) or nanonized (NALA) alaptide from BACTROBAN ${ }^{\circledR}$ Leciva through skin. $Q_{t}$ values are expressed as mean $\pm S D(n=5$ experiments).

As the current study represents a preliminary rapid in vitro screening, all the experiments were performed only in the time range from 0.5 to $2.0 \mathrm{~h}$. The values obtained from the permeation experiments were expressed as the cumulative permeated amount of the drug $\left(Q_{\mathrm{t}}[\mu \mathrm{g}]\right)$ per unit of skin surface area $\left(0.6359 \mathrm{~cm}^{2}\right.$, see Table 1). Due to the short time interval of experiments, steady-state permeation flux and lag time could not be calculated; however, this was not the aim of the experiments. The dependences of the cumulative permeated amount of the drug per unit of skin surface area in time are shown in Figure 2.

Based on the results obtained, it can be stated that mupirocin without ALA did not permeate within $1 \mathrm{~h}$ after application and the permeated amount of mupirocin started to increase rapidly after $1 \mathrm{~h}$; in $1.5 \mathrm{~h}$, the permeated concentration of mupirocin was slightly higher than with the addition of ALA. On the other hand, in the system containing mupirocin with ALA, the permeated amount of the drug increased approximately linearly with time $(r=0.988)$ during the whole experiment $(0-2 \mathrm{~h})$ and in 0.5 and $1 \mathrm{~h}$ it reached approx. 2.5-fold or 5-fold higher values than in the system containing mupirocin without ALA. Thus, it can be concluded that the application of ALA to mupirocin in BACTROBAN ${ }^{\circledR}$ Leciva caused a uniform linear increase within $1 \mathrm{~h}$ when the permeation through the skin with ALA was faster than the permeation without ALA. An absolutely different effect was observed with the system containing NALA: the addition of $1 \% \mathrm{w} / \mathrm{w}$ of NALA to BACTROBAN ${ }^{\circledR}$ Leciva led to a significant decrease of permeation (in fact, the blocking of permeation) of mupirocin from BACTROBAN ${ }^{\circledR}$ Leciva through the skin during the experiment $(0-2 \mathrm{~h})$, indicating that both mupirocin and alaptide can act curatively only on the surface of the skin. Although it was found that nanoparticles, especially solid lipid nanoparticles also enhanced skin penetration, primarily due to an increase in skin hydration caused by the occlusive film formed by these particles on the skin surface [43], and that NALA promoted permeation of various anti-inflammatory drugs, analgesics and antimicrobial chemotherapeutics through the skin in different studies [32,33], in this case, NALA blocked permeation of mupirocin from macrogol. The effect of the lipophilicity of the tested drug, as well as the effect of the applied medium/formulation used in this study on behaviour/properties of NALA as a permeation modifier will be the aim of further investigation. 
Based on the findings above, it can be assumed that the evaluated pharmaceutical composition of mupirocin can be used with success in combination with alaptide. As mentioned above, alaptide administered topically/locally supports/induces much faster regeneration and healing of the skin; therefore, it can be supposed than alaptide can potentiate the curative effect of mupirocin. The selection of the micronized or nanonized form of alaptide can influence the depth and the rate of permeation to the skin, i.e., the curative effect.

\section{Conclusions}

The ability of alaptide in micronized and nanonized forms to modify permeation of mupirocin into/through the porcine ear skin was examined using the Franz cell in the rapid preliminary in vitro screening. Micronized and nanonized alaptide applied in a concentration of $1 \% \mathrm{w} / \mathrm{w}$ related to the amount of mupirocin influenced the permeation/penetration of the drug from the BACTROBAN ${ }^{\circledR}$ Leciva macrogol ointment through the skin. According to the calculated cumulative permeated amount of the drug per unit of skin surface area, in time, mupirocin with the addition of micronized alaptide, permeated approx. 2.5fold or 5 -fold more in 0.5 and $1.0 \mathrm{~h}$ than without alaptide, i.e., micronized alaptide can significantly accelerate the impending effect of mupirocin within $1 \mathrm{~h}$, whereas nanonized alaptide inhibited the permeation of mupirocin from the macrogol ointment. This finding, as well as confirmation of the mechanism of action of alaptide, will be the aim of our next investigation. Nevertheless, on the basis of the preliminary results of the rapid preliminary screening, it can be concluded that alaptide combined with mupirocin can influence the depth and the rate of permeation of mupirocin into/through the skin. Moreover, alaptide can act as a skin protecting substance due to its skin curative effect.

Acknowledgements: This study was supported by the Grant Agency of the Czech Republic (Czech Science Foundation); project number GACR P304/11/2246.

\section{References}

[1] H.Y. Thong, H. Zhai, H.I. Maibach, Skin Pharmacology and Physiology 20 (2007) 272-282.

[2] I.B. Pathan, C.M Setty, Tropical Journal of Pharmaceutical Research 8 (2009) 173-179.

[3] R.K. Subedi, S.Y. Oh, M.K. Chun, H.K. Choi, Archives of Pharmacal Research 33 (2010) 339-351.

[4] J. Jampilek, K. Brychtova, Medicinal Research Reviews 32 (2012) 907-947.

[5] J. Jampilek, Journal of Bioequivalence \& Bioavailability 5 (2013) 233-235.

[6] B. Bhushan, Handbook of Nanotechnology, Springer-Verlag, Berlin-Heidelberg, 2004.

[7] C. Buzea, I.I. Pacheco, K. Robbie, Biointerphases 2 (2007) MR17-MR71.

[8] E. Corredor, P.S. Testillano, M.J. Coronado, P. Gonzalez-Melendi, R.F. Pacheco, C. Marquina, M.R. Ibarra, J.M. de la Fuente, D. Rubiales, A. Perez-de-Luque, M.C. Risueno, BioMed Central Plant Biology 9 (2009) 11 pages.

[9] A. Verma, F. Stellacci, Small 6 (2010) 12-21.

[10] M. Schneider, F. Stracke, S. Hansen, U.F. Schaefer, Dermato-Endocrinology 1 (2009) 197-206.

[11] B. Baroli, Journal of Pharmaceutical Sciences 99 (2010) 21-50.

[12] T.W. Prow, J.E. Grice, L.L. Lin, R. Faye, M. Butler, W. Becker, E.M. Wurm, C. Yoong, T.A. Robertson, H.P. Soyer, M.S. Roberts, Advanced Drug Delivery Reviews 63 (2011) 470-491.

[13] C.S.J. Campbell, L.R. Contreras-Rojas, M.B. Delgado-Charro, R.H. Guy, Journal of Controlled Release 162 (2012) 201-207.

[14] E. Kimura, Y. Kawano, H. Todo, Y. Ikarashi, K. Sugibayashi, Biological \& Pharmaceutical Bulletin 35 (2012) 1476-1486. 
[15] A.C. Watkinson, A.L. Bunge, J. Hadgraft, M.E. Lane, Pharmaceutical Research 30 (2013) 1943-1946.

[16] E. Kasafirek, J. Vanzura, I. Krejci, J. Krepelka, A. Dlabac, M. Valchar, (United Pharmaceutical Works \& Research Institute for Pharmacy and Biochemistry), Belg. 897843 (1984) \& CS 231227 (1986).

[17] S. Radl, E. Kasafirek, I. Krejci, Drugs of the Future 15 (1990) 445-447.

[18] E. Kasafirek, I. Krejci, Z. Hlinak, M. Valchar, K. Dobrovsky, A. Sturc A, (United Pharmaceutical Works \& Research Institute for Pharmacy and Biochemistry), US 5318973 (1994).

[19] J. Nedvidkova, E. Kasafirek, J. Nedvidek, K. Pacak, V. Schreiber, Endocrine Research 20 (1994) 39-46.

[20] Z. Hlinak, I. Krejci, S. Hynie, V. Klenerova, Neuroendocrinology Letters 29 (2008) 917-923.

[21] J. Vanzura, K. Kosar, E. Kasafirek, Toxicology Letters 31 (1986) 189-193.

[22] S. Blazickova, J. Rovensky, E. Kasafirek, M. Buc, Folia Biologica 42 (1996) 57-59.

[23] L. Korbova, J. Cizkova, J. Kohout, E. Kasafirek, I. Krejci, J. Vanzura, Journal of Czech Physicians 127 (1988) 1574-1577.

[24] L. Korbova, J. Kohout, E. Kasafirek, Gastroenterology and Hepatology 48 (1994) 170-182.

[25] E. Kasafirek, L. Korbova, J. Kohout, M. Jiraskova, I. Krejci, A. Galatik, (United Pharmaceutical Works \& Research Institute for Pharmacy and Biochemistry), CS 276270 (1992).

[26] J.A. McGrath, R.A. Eady, F.M. Pope, Rook's Textbook of Dermatology, 7th ed. T. Burns, S. Breathnach, N. Cox, C. Griffiths, (Eds)., Blackwell Publishing, Oxford, 2004, pp. 3-7.

[27] W. James, T. Berger, D. Elston. Andrews' diseases of the skin: Clinical dermatology, 10th ed., Saunders-Elsevier, Philadelphia, 2006, pp. 5-6.

[28] F.M. Watt, BioEssays 8 (1988) 163-167.

[29] R. Lapka, Journal of Pharmacy and Pharmacology, 43 (1991) 874-876.

[30] K. Kosar, J. Vanzura, Pharmazie, 43 (1988) 715-716.

[31] J. Jampilek, R. Opatrilova, A. Rezacova, Z Oktabec, P Pavek, V Kral, J. Dohnal, (Faculty of Pharmacy, University of Veterinary and Pharmaceutical Sciences Brno), CZ PV 2011-232 (2011), http://spisy.upv.cz/Applications/2011/PPVCZ2011 0232A3.pdf.

[32] J. Jampilek, R. Opatrilova, L. Coufalova, A. Cernikova, J. Dohnal, (Faculty of Pharmacy, University of Veterinary and Pharmaceutical Sciences Brno), WO/2013/020527 A1 (2013), http://patentscope.wipo.int/search/en/WO2013020527.

[33] J. Jampilek, A. Cernikova, R. Opatrilova, J. Dohnal, (Faculty of Pharmacy, University of Veterinary and Pharmaceutical Sciences Brno), CZ PV 2013-1000 (2013).

[34] R. Opatrilova, A. Cernikova, L. Coufalova, J. Dohnal, J. Jampilek, The Scientific World Journal, 2013 (2013), Article ID 787283, 8 pages, http://www.hindawi.com/journals/tswj/2013/787283/.

[35] A.T. Fuller, G. Mellows, M. Woolford, G.T. Banks, K.D. Barrow, E.B. Chain, Nature 234 (1971) 416-417.

[36] C.M. Thomas, J. Hothersall, C.L. Willis, TJ Simpson, Nature Reviews Microbiology 8, (2010) 281-289.

[37] Drug Bank - Mupirocin, http://www.drugbank.ca/drugs/DB00410 (December 12, 2013).

[38] E. Kasafirek, M. Rybak, I. Krejci, A. Sturs, E. Krepela, A. Sedo, Life Science 50 (1992) 187-193.

[39] T.J. Franz, Journal of Investigative Dermatology 64 (1975) 190-195.

[40] U. Jacobi, M. Kaiser, R. Toll, S. Mangelsdorf, H. Audring, N. Otberg, W. Sterry, J. Lademann, Skin Res Technol 13 (2007) 19-24.

[41] C. Herkenne, A. Naik, Y.N. Kalia, J. Hadgraft, Guy R.H., Pharmaceutical Research 23 (2006) 1850-1856.

[42] W. Meyer, K. Schwarz, K.T. Neurand, Current Problems in Dermatology 7 (1978) 39-52.

[43] H.A.E. Benson, Current Drug Delivery 2 (2005) 23-33. 